\title{
AGE AND GENDER DIFFERENCES IN ACUTE STROKE HOSPITAL PATIENTS
}

\author{
Vanja Bašić Kes ${ }^{1}$, Miljenka-Jelena Jurašić ${ }^{1}$, Iris Zavoreo ${ }^{1}$, Marijana Lisak ${ }^{1}$, Vjekoslav Jeleč² and Lucija \\ Zadro Matovina ${ }^{1}$
}

\begin{abstract}
${ }^{1}$ University Department of Neurology, Sestre milosrdnice University Hospital Center; ${ }^{2}$ Department of Neurosurgery, Dubrava University Hospital, Zagreb, Croatia
\end{abstract}

\begin{abstract}
SUMMARY - Stroke is the second leading cause of death and the most important cause of adult disability worldwide and in Croatia. In the past, stroke was almost exclusively considered to be a disease of the elderly; however, today the age limit has considerably lowered towards younger age. The aim of this study was to determine age and gender impact on stroke patients in a Croatian urban area during one-year survey. The study included all acute stroke patients admitted to our Department in 2004. A compiled stroke questionnaire was fulfilled during hospitalization by medical personnel on the following items: stroke risk factors including lifestyle habits (smoking and alcohol), pre-stroke physical ability evaluation, stroke evolution data, laboratory and computed tomography findings, outcome data and post-stroke disability assessment. Appropriate statistical analysis of numerical and categorical data was performed at the level of $\mathrm{p}<0.05$. Analysis was performed on 396 patients, 24 of them from the younger adult stroke group. Older stroke patients had worse disability at hospital discharge and women had worse disabilities at both stroke onset and hospital discharge, probably due to older age at stroke onset. Younger patients recovered better, while older patients had to seek secondary medical facilities more often, as expected. The most important in-hospital laboratory findings in young stroke patients were elevated lipid levels, while older patients had elevated serum glucose and C-reactive protein. Stroke onset in younger patients most often presented with sudden onset headache; additionally, onset seizure was observed more frequently than expected. Stroke risk factor analysis showed that women were more prone to hypertension, chronic heart failure and atrial fibrillation, whereas men had carotid disease more frequently, were more often smokers and had higher alcohol intake. Additionally, age analysis showed that heart conditions and smoking were more prevalent among older stroke patients. In conclusion, considerable differences were established between age and gender stroke patient groups, confirming the need of permanent national stroke registry and subsequent targeted action in secondary care, and prevention with education on risk factors, preferably personally tailored.
\end{abstract}

Key words: Stroke; Risk factors; Croatia; Sex; Age; Surveys and questionnaires

\section{Introduction}

Stroke is the second most common cause of death and the most important cause of adulthood disability

Correspondence to: Miljenka-Jelena Jurašic, $M D, P h D$, University Department of Neurology, Sestre milosrdnice University Hospital Center, Vinogradska c. 29, HR-10000 Zagreb, Croatia

E-mail: mjjurasic@gmail.com

Received March 25, 2013, accepted December 14, 2015 worldwide and in Croatia ${ }^{1}$. Croatian statistical reports rank cerebrovascular mortality as the second most common cause of death; however, for women, stroke leads on mortality scales ${ }^{2}$. Stroke can affect individuals of any age, yet both stroke incidence and prevalence increase sharply with age ${ }^{3}$. Worldwide, the incidence of stroke exponentially increases after 30 years of age with about $95 \%$ of strokes occurring in people aged 45 and older, and over $65 \%$ in those older than 
$65^{4}$. Men are more likely to suffer from stroke (by onefourth of cases), however, women hold the majority of stroke mortality due to their increased life $\operatorname{span}^{5}$. Additionally, women are more likely to have poor functional outcomes after stroke than men, which could be partially attributed to older age at stroke onset ${ }^{5}$. The most important non-modifiable stroke risk factors are age, gender and race. Modifiable risk factors for stroke include hypertension, atrial fibrillation, dyslipidemia, diabetes mellitus, cigarette smoking (both active and passive), heavy alcohol and drug use, lack of physical activity, obesity and unhealthy diet ${ }^{5-10}$. Modifiable risk factors also differ between men and women: women will more likely suffer from atrial fibrillation and hypertension, and men from coronary and carotid artery disease, peripheral arterial disease (PAD), and are more likely to have a history of tobacco smoking or alcohol overuse ${ }^{5,8}$. Since epidemiological data help in creating better stroke management and prevention guidelines, we aimed to retrospectively evaluate age and gender differences in an urban population (City of Zagreb) of stroke patients admitted to our Department for acute stroke during a one-year period.

\section{Subjects and Methods}

The investigation was performed on 396 stroke patients admitted to our Department between January 1 and December 31, 2004. All subjects or their families agreed to participate by signing the informed consent form approved by the Hospital Ethics Committee.

Inclusion criteria were simple, i.e. sudden stroke occurrence. Patients with transient ischemic attack (TIA) or other neurologic or systemic diseases were excluded from further evaluation in this study. A stroke risk factor questionnaire was assembled and performed by medical personnel during hospitalization. It included modifiable and non-modifiable stroke risk factors: age (young adult stroke group $\leq 45$ years and older adult stroke group $>45$ years); gender; Barthel index before stroke; presence of hypertension (repeated blood pressure measurements $>140 / 90 \mathrm{~mm} \mathrm{Hg}$ and patient history) with or without hypertensive therapy prior to stroke (yes/no, $y / n$ ), elevated LDL cholesterol ( $>3 \mathrm{mmol} / \mathrm{L}$ and patient history) and/or diabetes mellitus (previously diagnosed - patient history) with or without therapy prior to stroke $(y / n)$; smoking $(y / n)$; alcohol consumption (low 0-10 drinks/week, moderate 14 drinks/week, and high 14-35 drinks/week); prior heart condition or atrial fibrillation $(\mathrm{y} / \mathrm{n})$; prior claudications $(\mathrm{y} / \mathrm{n})$; history of migraine $(\mathrm{y} / \mathrm{n})$; and prior TIA (y/n). Stroke was evaluated as follows: mode of onset (sudden, progressive, fluctuating); neurologic deficit alone $(\mathrm{y} / \mathrm{n})$; loss of consciousness at onset $(\mathrm{y} / \mathrm{n})$; onset headache $(\mathrm{y} / \mathrm{n})$; onset seizure $(\mathrm{y} / \mathrm{n})$; deficit at onset $(y / n)$, Rankin score prior to stroke occurrence, National Institute of Health Stroke Scale (NIHSS) score; computed tomography (CT) stroke distribution (ischemic/hemorrhagic, anterior/posterior, normal/ non-pathologic findings) during the first 24 hours; and Color Doppler Flow Imaging (CDFI) findings (normal, plaques and low to moderate grade stenosis of extracranial cerebral arteries, high grade stenosis or occlusion of extracranial cerebral arteries according to internationally established criteria). Other instrumental assessment was performed if medically indicated and was used in this study to assess TOAST classification and therefore is not reported in full length; it included transthoracic echocardiography, transesophageal echocardiography, conventional angiography, brain magnetic resonance angiography (MRA) and brain magnetic resonance imaging (MRI). During hospital stay (generally, 10 days), several laboratory results were recorded: erythrocyte sedimentation rate (ESR); leukocyte count; fasting blood glucose (FBG); fasting total cholesterol level (TC); fasting HDL level; fasting LDL level; fasting triglyceride level (TG); and $\mathrm{C}$-reactive protein (CRP). Before discharge, the following was determined: stroke mechanism according to TOAST classification, Barthel index (BI) and modified Rankin scores (mRS), and the place of referral (home, rehabilitation facility, and secondary chronic patient institution).

Statistical evaluations were conducted using SPSS (version 8.0 for Windows). All numerical variables were tested using T-test (parametric data) and Kruskal-Wallis test (nonparametric data) for ranked variables, while categorical variables (example: hypertension: yes, no, yes + therapy) were tested using $\chi^{2}-$ test or Fisher's exact test if the expected frequency per cell was less than 5 . The level of statistical significance was set at $\mathrm{p}<0.05$. 
Table 1. Stroke mechanism by type and TOAST classification, with measures of disability: NIHSS scale, Barthel index and modified Rankin scores; age and gender stratification

\begin{tabular}{|l|c|c|c|c|}
\hline & $\begin{array}{c}\text { Older stroke } \\
(372 \text { patients })\end{array}$ & $\begin{array}{c}\text { Young stroke } \\
(24 \text { patients })\end{array}$ & $\begin{array}{c}\text { Women } \\
(210 \text { patients })\end{array}$ & $\begin{array}{c}\text { Men } \\
(186 \text { patients })\end{array}$ \\
\hline Stroke type & \multicolumn{5}{|l|}{} \\
\hline Hemorrhagic stroke & 52 & 3 & 33 & $22^{*}$ \\
\hline Ischemic stroke subtype -TOAST classification & \multicolumn{5}{|l|}{} \\
\hline Large artery atherosclerosis & 42 & $3^{*}$ & 16 & $29^{*}$ \\
\hline Cardioembolism & 85 & $5^{*}$ & 54 & 36 \\
\hline Small artery occlusion & 71 & 4 & 34 & $41^{*}$ \\
\hline Other cause & 4 & $3^{*} \dagger$ & 4 & 3 \\
\hline Undetermined cause & 118 & $6^{*}$ & 69 & $55^{*}$ \\
\hline Disability measures & \multicolumn{5}{|l|}{} \\
\hline NIHSS (CI) & $10.55(1.15)$ & $9.76(1.08)$ & $11.68(1.16)$ & $9.18(1.15)^{*}$ \\
\hline BI before stroke (CI) & $90.24(3.23)$ & $100(3.08)^{*}$ & $87.56(3.30)$ & $90.59(3.14)$ \\
\hline BI after stroke (CI) & $59.16(14.06)$ & $71.09(12.28)^{*}$ & $47.44(13.50)$ & $57.17(14.46)^{*}$ \\
\hline mRS (CI) & $3.29(0.66)$ & $2.30(0.66)^{*}$ & $3.04(0.67)$ & $3.52(0.63)^{*}$ \\
\hline
\end{tabular}

* $\mathrm{p}<0.05$; †arterial dissection in 2 patients and antiphospholipid syndrome in 1 patient; $\mathrm{CI}=$ confidence interval; NIHSS = National Institute of Health Stroke Scale; BI = Barthel index; $\mathrm{mRS}=$ modified Rankin scale

\section{Results}

During the study period, 396 stroke patients were admitted to our Department: 210 (53.0\%) women and 186 (47.0\%) men; 24 of them were young adult stroke patients (5 women and 19 men). The mean age of young adult and older stroke patients was $42.07 \pm 4.80$ and $75.35 \pm 8.03$ years, respectively $(\mathrm{p}<0.05)$. The older the patients, the more women were recruited, yielding a slight female prevalence in the study population.

Stroke incidence in the study population was estimated to 264 (estimated size of the population at risk was 150 000) and case-fatality in the first 10 days was $8.83 \%$ ( 35 cases). Younger adult stroke was represented in our population sample in $8 \%$ of cases. Additionally, there were 75 (19\%) cases of recurrent stroke; among them, three patients $(2$ women and 1 man) were readmitted within 30 days, all three in the older stroke group. Stroke recurrence was not related to age or pathologic stroke type.

\section{Stroke mechanism - age and gender association}

In the study population, CT and CDFI were performed in all cases, MR techniques in 34.84\% $(\mathrm{n}=138)$, standard angiography in $14.89 \%(\mathrm{n}=59)$, and transthoracic or transesophageal echocardiography in
$35.01 \%(\mathrm{n}=139)$. At the time of evaluation, all diagnostic findings were available to the investigators as final written specialist opinion.

The most prevalent stroke mechanism in the young adult stroke patients was ischemic stroke in 21 patients and hemorrhagic stroke in 3 patients ( 2 patients with intraparenchymal hemorrhage and 1 with subarachnoid hemorrhage (SAH)). In the older stroke group, ischemic stroke was recorded in $320(86.02 \%)$ and hemorrhagic stroke in 59 (15.86\%) patients, including 48 patients with intraparenchymal hemorrhage and 11 with SAH) (Tables 1 and 2). Using TOAST classification, ischemic strokes differed statistically in the following categories: cardioembolism (more frequent in young stroke patients), other causes, i.e. arterial dissection in younger stroke patients (2 patients) and patients with cryptogenic stroke in favor of older stroke patients (Table 1).

Gender stratification showed that hemorrhagic stroke was more frequently present in female patients, $15.71 \%$ vs. $11.83 \%$ in men $(\mathrm{p}<0.05)$. SAH was equally present in both genders $(2.86 \%$ in women and $2.15 \%$ in men) (Table 2). Using TOAST classification, ischemic strokes differed statistically in the following categories: large artery atherosclerosis and small artery occlusion were more frequent in men, $15 \%-59 \%$ vs. 
$7.62 \%$ and $22.04 \%$ vs. $16.19 \%$, respectively; women were more prone to cryptogenic stroke $(32.86 \%$ vs. 29.57\%). Finally, arterial dissection was detected in 8 (2.15\%) patients (Table 1 ).

\section{Stroke disability measures}

Age analysis showed no statistically significant difference between onset deficit in young adult versus older stroke patients measured by NIHSS score: 9.76 vs. 10.55. However, women were more disabled at stroke onset, NIHSS 11.68 vs. 9.18.

The mean BI in the young adult stroke group before stroke occurrence was 100 vs. 90.24 in the older stroke group $(\mathrm{p}<0.05)$. The mean BI and mRS scores at discharge were worse by 11.93 points and 0.99 , respectively, in the older stroke group $(\mathrm{p}<0.05)$ (Table 1). Also, greater discharge disability by 9.73 (BI) and $0.48(\mathrm{mRS})(\mathrm{p}<0.05)$ was seen in women (Table 1$)$.

\section{Stroke outcome}

In the young adult stroke group, the outcome was as follows: improvement in 19/24, stable-unchanged in $2 / 24$, worsening in $2 / 24$ patients, and one death was recorded. In the older stroke group, the outcome was as follows: improvement in 208 (55.9\%), stableunchanged in 110 (29.6\%), worsening in 41 (11.1\%) patients, and 13 (3.4\%) deaths were recorded ( $p>0.05)$.

Upon discharge, younger patients usually went home (13/24), to a rehabilitation facility (10/24), or were referred to a secondary chronic patient institution (1/24). Similar distribution was also observed in the older stroke group: 186 (50.1\%) patients went home, $120(32.3 \%)$ to a rehabilitation facility, or were referred to a secondary chronic patient institution $(\mathrm{n}=66 ; 17.6 \%)(\mathrm{p}>0.05)$. Not surprisingly, after hospital discharge, women tended to go for rehabilitation or to chronic patient facilities more frequently than

Table 2. Difference in clinical stroke appearance; age and gender stratification

\begin{tabular}{|c|c|c|c|c|c|}
\hline & & $\begin{array}{l}\text { Older stroke } \\
\text { (372 patients }\end{array}$ & $\begin{array}{l}\text { Young stroke } \\
\text { (24 patients) }\end{array}$ & $\begin{array}{c}\text { Women } \\
\text { (210 patients) }\end{array}$ & $\begin{array}{c}\text { Men } \\
\text { (186 patients) }\end{array}$ \\
\hline Stroke course (first & $24 \mathrm{~h})$ & & & & \\
\hline Fluctuating & & 19 & $0^{*}$ & 11 & 8 \\
\hline Unknown & & 16 & 0 & 8 & 8 \\
\hline Progressive & & 58 & $6^{*}$ & 26 & $38^{*}$ \\
\hline Regressive & & 16 & 1 & 10 & 7 \\
\hline Stable deficit & & 263 & 17 & 155 & 125 \\
\hline Stroke onset & & & & & \\
\hline Neurologic deficit & & 239 & $7^{*}$ & 127 & $119^{*}$ \\
\hline $\mathrm{LoC}$ & & 42 & 3 & 25 & 20 \\
\hline $\mathrm{HO}^{* * *}$ & & 75 & $11^{*}$ & 48 & 38 \\
\hline $\mathrm{SO}^{* *}$ & & 16 & $3^{*}$ & 10 & 9 \\
\hline Extracranial large ar & rtery dis & & & & \\
\hline CDFI & $\mathrm{p} / 1-\mathrm{m}$ & 235 & 15 & 140 & $110^{*}$ \\
\hline & s/o & 72 & 4 & 34 & $42^{*}$ \\
\hline Computerized tomo & ography & & & & \\
\hline Anterior territory & & 157 & 10 & 96 & 85 \\
\hline Posterior territory & & 37 & $4^{*}$ & 19 & $23^{*}$ \\
\hline Normal finding & & 119 & 7 & 58 & 56 \\
\hline Hemorrhagic stroke & & 48 & 2 & 31 & $18^{*}$ \\
\hline SAH & & 11 & 1 & 6 & 4 \\
\hline
\end{tabular}

**two sided; $\mathrm{LoC}=$ loss of consciousness; $\mathrm{OH}$ = onset headache; $\mathrm{OS}$ = onset seizure; $\mathrm{CDFI}=$ Color Doppler Flow Imaging; $\mathrm{p} / 1-\mathrm{m}=\mathrm{plaques}$ and low to moderate grade stenosis of extracranial cerebral arteries; s/o = high stenosis or occlusion of extracranial cerebral arteries; $\mathrm{SAH}$ = subarachnoid hemorrhage 
Table 3. Laboratory hospital findings in stroke patients; age stratification

\begin{tabular}{|l|c|c|}
\hline & $\begin{array}{c}\text { Older } \\
(\text { mean } \pm \mathrm{SD})\end{array}$ & $\begin{array}{c}\text { Young } \\
(\text { mean } \pm \mathrm{SD})\end{array}$ \\
\hline $\mathrm{ESR}(\mathrm{mm} / \mathrm{h})$ & $20.56 \pm 16.23$ & $22.19 \pm 18.34$ \\
\hline $\mathrm{L}\left(10^{* *} 9 / \mathrm{L}\right)$ & $9.68 \pm 5.62$ & $9.44 \pm 3.97$ \\
\hline $\mathrm{SG}(\mathrm{mmol} / \mathrm{L})$ & $8.66 \pm 5.23$ & $7.99 \pm 3.30^{* *}$ \\
\hline $\mathrm{TC}(\mathrm{mmol} / \mathrm{L})$ & $5.52 \pm 4.97$ & $5.95 \pm 1.47^{* *}$ \\
\hline $\mathrm{LDL}(\mathrm{mmol} / \mathrm{L})$ & $3.36 \pm 1.32$ & $4.75 \pm 2.32^{* *}$ \\
\hline $\mathrm{HDL}(\mathrm{mmol} / \mathrm{L})$ & $1.42 \pm 1.16$ & $1.33 \pm 0.41^{* *}$ \\
\hline $\mathrm{TG}(\mathrm{mmol} / \mathrm{L})$ & $1.58 \pm 1.09$ & $2.26 \pm 1.51^{*}$ \\
\hline $\mathrm{CRP}(\mathrm{mg} / \mathrm{L})$ & $52.36 \pm 42.98$ & $38.6 \pm 16.52^{* *}$ \\
\hline
\end{tabular}

Patients were categorized into those with normal and those with pathologic values according to our University Hospital Center Laboratory, the number presented in the table shows the number of patients with pathologic values; ${ }^{*} \mathrm{p}<0.05 ;{ }^{* *} \mathrm{p}<0.001 ; \mathrm{SD}=$ standard deviation; $\mathrm{ESR}$ = erythrocyte sedimentation rate; $\mathrm{L}=$ leukocyte count; $\mathrm{SG}=$ serum glucose level; $\mathrm{TC}=$ total cholesterol; $\mathrm{LDL}=$ low density lipoprotein; HDL = high density lipoprotein; $\mathrm{TG}=$ triglycerides; $\mathrm{CRP}=\mathrm{C}$-reactive protein

men: 69 (33.0\%) vs. $51(27.4 \%)$ and $79(37.6 \%)$ vs. 48 (25.6\%), respectively $(\mathrm{p}<0.05)$.

\section{Stroke presentation and in-hospital diagnostics}

Stroke usually presented with a stable acute neurologic deficit regardless of age or gender. However, younger patients tended to have progressive course in the first $24 \mathrm{~h}$, and in the older group men were more prone to progressive stroke evolution $(20.43 \%$ vs. $12.38 \%, \mathrm{p}<0.05)$. Some older patients presented with fluctuating stroke evolution (5.11\%) as opposed to none in the young stroke group $(\mathrm{p}<0.05)$ (Table 2).

Sudden neurologic deficit was the first and single reported clinical stroke sign in $62.12 \%$, more often in the older stroke group $(\mathrm{p}<0.05)$ and slightly more so in men $(63.98 \%)(p<0.05)$. Age analysis revealed that onset headache and onset seizure were statistically more often present in the young adult stroke group. Headache was seen in $20.16 \%$ of older group patients and in almost half of younger patients. Onset seizure was seen in $3 / 24$ younger patients and in $4.30 \%$ of older patients (Table 2). Equally present regardless of gender were loss of consciousness (11.4\%), onset headache (21.7\%), and onset seizure (5\%), all without statistical significance (Table 2).
Computerized tomography showed that younger patients had posterior territory infarction more often $(p<0.05)$, while gender analysis revealed more frequent posterior territory involvement in men $(12.36 \%$ vs. 9.05\%) and a higher incidence of hemorrhagic stroke in women (14.76\% vs. 9.68\%) (Table 2). CDFI examination revealed no age preponderance, but severe stenosis or occlusion predominated in men $(22.58 \%$ vs. $16.19 \%)$ as opposed to minimal-to-moderate carotid atherosclerotic affection observed in women (66.67\% vs. 59.14\%) (Table 2).

Laboratory hospital findings revealed higher values of serum glucose and CRP in the older stroke group and worse lipidogram in the young adult stroke group (Table 3). Gender analysis yielded no statistically significant difference except for a tendency to worse lipidogram among men.

\section{Stroke risk factor analysis - age and gender association}

Ischemic heart disease, chronic heart failure, atrial fibrillation and TIA were found to be significantly more prevalent in older patients $(\mathrm{p}<0.05)$, while the same was recorded for smoking in younger stroke patients $(p<0.001)$. General smoking prevalence in the study population was $32.32 \%$ (Table 4).

Generally, women were older by about 4 years at stroke onset. Women were also found to have statistically more frequently hypertension $(83.81 \%$ vs. $63.35 \%)$, atrial fibrillation ( $24.76 \%$ vs. $14.51 \%)$ and chronic heart failure (30.00\% vs. 19.89\%), or having experienced TIA (16.19\% vs. 7.00\%). Men were more frequently smokers $(38.17 \%$ vs. $27.14 \%)$ and heavier alcohol consumers (8.60\% vs. 2.38\%). Women tended to disregard their hyperlipidemia $(48.48 \%)$, diabetes (22.64\%) and hypertension (8.52\%) by not taking oral medications. Men followed in the same manner, but showed greater compliance with pharmacological therapy with $33.33 \%$ not taking medication for hyperlipidemia, $25.92 \%$ for diabetes mellitus and $14.72 \%$ for hypertension. None of these trends was statistically significant within the gender group (Table 4).

\section{Discussion}

Stroke incidence in our population was similar to that expected in Croatia, only slightly less than expected in the urban Zagreb area ${ }^{11}$. The proportion of 
Table 4. Stroke risk factor prevalence; age and gender stratification

\begin{tabular}{|c|c|c|c|c|c|}
\hline \multicolumn{2}{|c|}{$($ Mean age $\pm \mathrm{SD})$} & $\begin{array}{c}\text { Elderly } \\
(75.35 \pm 8.03)\end{array}$ & $\begin{array}{c}\text { Young } \\
(42.07 \pm 4.80)\end{array}$ & $\begin{array}{c}\text { Women } \\
(77.28 \pm 6.20)\end{array}$ & $\begin{array}{c}\text { Men } \\
(73.31 \pm 5.86)\end{array}$ \\
\hline \multirow{3}{*}{ Hypertension } & Yes & 259 & 12 & 161 & $110^{*}$ \\
\hline & Yes, wth & 31 & 3 & 15 & $19^{*}$ \\
\hline & No & 82 & 9 & 34 & 57 \\
\hline \multirow{3}{*}{ Hyperlipidemia } & Yes & 36 & 3 & 17 & 22 \\
\hline & Yes, wth & 24 & 3 & 16 & 11 \\
\hline & No & 312 & 18 & 177 & 153 \\
\hline \multirow{3}{*}{$\begin{array}{l}\text { Diabetes } \\
\text { mellitus }\end{array}$} & Yes & 77 & 4 & 41 & 40 \\
\hline & Yes, wth & 24 & 2 & 12 & 14 \\
\hline & No & 271 & 18 & 157 & 132 \\
\hline \multirow{2}{*}{$\begin{array}{l}\text { Ischemic heart } \\
\text { disease } \dagger\end{array}$} & Yes & 76 & $1^{*}$ & 35 & 42 \\
\hline & No & 296 & 23 & 175 & 144 \\
\hline \multirow{2}{*}{$\begin{array}{l}\text { Chronic heart } \\
\text { failure } \dagger\end{array}$} & Yes & 100 & $0^{*}$ & 63 & $37^{*}$ \\
\hline & No & 272 & 24 & 148 & 148 \\
\hline \multirow{2}{*}{$\begin{array}{l}\text { Atrial } \\
\text { fibrillation } \dagger\end{array}$} & Yes & 79 & $0^{*}$ & 52 & $27^{*}$ \\
\hline & No & 293 & 24 & 158 & 159 \\
\hline \multirow{2}{*}{ TIA $\dagger$} & Yes & 47 & $0^{*}$ & 34 & $13^{*}$ \\
\hline & $\mathrm{No}$ & 325 & 24 & 176 & 173 \\
\hline \multirow{2}{*}{ Claudication } & Yes & 7 & 0 & 3 & 4 \\
\hline & No & 365 & 24 & 207 & 182 \\
\hline \multirow{2}{*}{ Migraine } & Yes & 2 & 1 & 3 & 0 \\
\hline & $\mathrm{No}$ & 369 & 24 & 206 & 187 \\
\hline \multirow{3}{*}{ Smoking } & Yes & 117 & $11^{* * *}$ & 57 & $71^{* *}$ \\
\hline & Former & 34 & 2 & 7 & 29 \\
\hline & No & 221 & 11 & 192 & 124 \\
\hline \multirow{3}{*}{$\begin{array}{l}\text { Alcohol } \\
\text { intake }\end{array}$} & Regular & 19 & 2 & 5 & $16^{* *}$ \\
\hline & Moderate & 59 & 8 & 11 & $56^{* *}$ \\
\hline & No & 294 & 14 & 193 & 115 \\
\hline
\end{tabular}

${ }^{*} \mathrm{p}<0.05 ;{ }^{* *} \mathrm{p}<0.001 ; \dagger$ two sided; $\mathrm{SD}=$ standard deviation; $\mathrm{wth}=$ without therapy; TIA = transient ischemic attack

hemorrhagic stroke, recurrent stroke cases and casefatality was also lower than expected by the same author ${ }^{11}$. This is in accordance with several studies from both western and eastern countries, which revealed that stroke incidence increased with age and that global stroke burden was among the first few diseases causing both high mortality and adulthood disability ${ }^{12-14}$. Ischemic stroke usually affects those aged over 65, with atherosclerosis as the predominant etiopathogenic cause. Additionally, older patients suffer from cryptogenic stroke in about one-third of cases ${ }^{15}$, and the same held true for our population sample. Ko-
lominsky-Rabas et al. showed that men suffered more from large artery atherosclerosis and small artery occlusion, while women had a greater incidence of cardioembolism ${ }^{15}$. Similar percentages were revealed in our study and further corroborated by our CDFI findings of a higher carotid atherosclerosis incidence in men. On the other hand, in young stroke patients, the etiology differs following this order of significance: cardioembolism, arterial dissection, migraine, drug use, use of oral contraceptives (OC), antiphospholipid syndrome (APLAS), inherited coagulation disorders and rare causes of non-atherosclerotic arteriopathies, 
which combined comprise about one-third of all cas$\mathrm{es}^{16-18}$. The same was confirmed in our study, where among other causes arterial dissection and APLAS were also recorded. Small artery occlusion in younger stroke patients is usually associated with tobacco smoking ${ }^{16}$, which corresponded to the proportion of small artery occlusion in our patients and the proportion of smokers in our young patient group (almost half of all patients). This may also be the explanation for the slightly more frequent posterior territory affection. Namely, our young stroke group consisted of 19 men and only 5 women. Considering stroke etiology classification in our study, we used the standard TOAST classification, but the recently developed SSS-TOAST and automated CCS TOAST questionnaire (available online at: https://ccs.mgh.harvard.edu/ ccs_title.php) offer the possibility of good inter-center data correspondence and is advised in all future stroke epidemiology research ${ }^{19}$.

Stroke disability measures were as expected, i.e. there was no prior neurologic deficit in the younger age patient group with better early recovery. Women were worse before stroke (only a trend) and statistically worse at hospital discharge (BI and $\mathrm{mRS}$ scores), which explains why they were more often readmitted to rehabilitation at secondary chronic medical facilities. Greater neurologic deficit and recovery is probably due to somewhat higher age at stroke onset (4 years), lesser personal care prior to illness and home care after hospital discharge, or some still unknown factors. Similar age difference between men and women at stroke onset is also reported by other stroke investigators ${ }^{20}$. Additionally, in the literature, quality of care for women with ischemic stroke is generally lower than that for men, and women are unfortunately less likely to be discharged home ${ }^{20,21}$.

In our study, case-fatality was about the same irrespective of gender, but greater among older stroke patients, as expected. Similar was observed by Andersen et al., who found that age and stroke severity were the only significant predictors of fatality within the first post-stroke week and were associated with late case-fatality as well ${ }^{22}$.

Clinically, younger adult stroke group differed from the older counterparts in more frequent progressive stroke and no fluctuating stroke course recorded in the first 24 hours. Onset headache and onset sei- zure were also more frequent in the younger patient group. Similar was reported by Nedeltchev et al. ${ }^{23}$ in 2004, who additionally concluded that severe neurologic deficits at presentation, total anterior circulation stroke, and diabetes mellitus predicted unfavorable outcome, whereas previous TIA was associated with an increased risk of stroke recurrence. Most of our patients, however, had their stroke only in the partial anterior territory. Furthermore, the only death recorded in the young stroke group was not a consequence of stroke size or of affected cerebral territory, but was caused by concomitant systemic infection.

Considering laboratory data, statistically significant were elevated serum glucose and CRP in the older group, while total cholesterol, LDL cholesterol and triglycerides were higher in the younger group. These findings in the older group were as expected due to age and are important in predicting short- and long-term stroke mortality ${ }^{24,25}$.

Our study managed to select eight risk factors as most common in stroke patients regardless of age and gender: arterial hypertension, hyperlipidemia, diabetes mellitus, ischemic heart disease, chronic heart failure, atrial fibrillation, smoking and higher alcohol intake. The INTERSTROKE study, however, isolated twelve risk factors that were associated with $90 \%$ of stroke risk: arterial hypertension, smoking, waist-to-hip ratio, diet, physical activity, diabetes mellitus, alcoholism, stress, depression, cardiac conditions and Apo B/ Apo $\mathrm{A}^{12}$. Although our results are limited, they pointed to the 'life's simple 7' as advised by the American Heart Association, stating that targeted interventions to reduce blood pressure, serum glucose and controlling cholesterol along with promotion of smoking cessation, regular physical activity and healthy diet with healthy body weight could substantially reduce the burden of stroke. Additionally, CRP levels can be used for indirect assessment of physical inactivity, as recently suggested by Esteghamati et al. ${ }^{26}$. Recently, risk factor evaluation is especially important in future management of patients with TIA compared to those with stroke $^{27}$. The results reported by Lovrenčić-Huzjan et al. showed difference between the two groups regarding risk factor prevalence: hypertension, hyperlipidemia and pathologic CDFI findings were more frequent among TIA patients, while diabetes, atrial fibrillation, previous stroke and ischemic heart disease 
were more often associated with stroke occurrence ${ }^{27}$. Therefore, it is important to identify all the potential stroke risk factors both in primary and secondary stroke prevention. The issue, however, is not only to recognize stroke risk factors, but also to act upon their discovery. It appears, from our results, that hypertension, hyperlipidemia and especially diabetes mellitus were not taken seriously enough in all patients, even more so in women. This may be due to personal or general practitioner negligence, so appropriate medication was not administered prior to the evolution of clinical manifestations. Saleem et al. pointed that physician's attitude, patient's past experiences, and knowledge related to hypertension were the major contributing factors resulting in non-adherence to therapy ${ }^{28}$. Conclusively, data from this study indicate margins for stroke management improvement.

Age analysis for stroke risk factors found that age at stroke onset revealed different risk factor prevalence regarding age association, isolating only smoking as being more prevalent among young adult stroke patients. Similar was reported by a group of Italian authors who analyzed younger stroke groups and also found lifestyle factors such as smoking and alcohol intake to be important issues for stroke occurrence at a younger age $\mathrm{e}^{29}$. Additionally, since younger stroke adult group consisted mostly of men, it was not surprising that no OC use was reported and that only one patient had a history of migraine. More common at older age, though, were heart conditions including atrial fibrillation, ischemic heart disease and chronic heart failure, as well as TIA. These results are in accordance with the Framingham study in which heart conditions were also isolated as important risk factors in elderly stroke patients ${ }^{30}$. In our study, gender stroke risk analysis showed that hypertension, chronic heart failure, atrial fibrillation and TIA were more often recorded in women, while men were prone to lifestyle pivots such as smoking and increased alcohol intake. Importantly, in previous studies, hypertension alone carried the risk for stroke occurrence in 35\%-50\% of all clinical stroke cases ${ }^{31}$, which may be used to explain higher hemorrhagic stroke incidence in women. Additionally, Niewada et al. in the International Stroke Trial observed older onset age, worse case disability, hypertension with higher blood pressure values and atrial fibrillation as the predictors of poor outcome ${ }^{32}$.
We should name several limitations of this study. Some data were not carefully monitored and were found unreliable and consequentially excluded from the present analysis. These were family history, waistto-hip ratio, diet information, exposure to stress, physical activity level, and coexistence of depression, lipoprotein analysis (Apo B/Apo $A_{1}$ ) and use of a thrombolytic agent. Additionally, apart from the aforementioned data, one should obtain more comprehensive laboratory data on an even larger stroke patient base. Finally, at least two-year follow up is required for monitoring of management, complications, survival and mortality statistics according to stroke subtypes.

In conclusion, since we confirmed considerable differences with age and gender patient stratification, it is obvious that early community stroke risk factor assessment is necessary along with patient education regarding modifiable risk factor management, assessment of therapy adherence and long-term specialist support to patients and general practitioners. Such action is applicable and warranted for both primary and secondary prevention. Also, the national stroke registry should be formed to collect all necessary information and to provide sufficient data for statistical analysis and targeted action for stroke burden reduction.

\section{References}

1. Mathers CD, Boerma T, Ma Fat D. Global and regional causes of death. Br Med Bull. 2009;92:7-32, doi: 10.1093/ $\mathrm{bmb} / \mathrm{ldp} 028$.

2. Cardiovascular Disease In Croatia, Croatian Statistical Analysis 2012. Available at: http://www.hzjz.hr/sluzbe/sluzba-zaepidemiologiju/odjel-za-nadzor-i-istrazivanje-ne-zaraznihbolesti/odsjek-za-srcano-zilne-bolesti/ (retrieved November 2015)

3. Marini C, Triggiani L, Cimini N, et al. Proportion of older people in the community as a predictor of increasing stroke incidence. Neuroepidemiology. 2001;20(2):91-5.

4. WHO Disease and Injury Country Estimates for 2008 and 2004. Geneva: World Health Organization. Available at: http://www.who.int/healthinfo/global_burden_disease/estimates_country/en/index.html (retrieved November 2015)

5. Report of Stroke Progress Review, September 2006. Available at: http://www.ninds.nih.gov/find_people/groups/stroke_ prg /09_2006_stroke_prg_report.htm\#STROKE (retrieved August 2015)

6. Thomson R. Evidence based implementation of complex interventions. 2009. BMJ. 339:b3124, doi: 10.1136/bmj.b3124. 
7. Hankey GJ. Smoking and risk of stroke. J Cardiovasc Risk. 1999;6(4):207-11.

8. Reynolds K, Lewis B, Nolen JD, Kinney GL, Sathya B, He J. Alcohol consumption and risk of stroke: a meta-analysis. JAMA. 2003;2289(5):579-88. Erratum in: Lewis B, Brian L. JAMA. 2003;289(21):2798.

9. Sloan MA, Kittner SJ, Feeser BR, et al. Illicit drug-associated ischemic stroke in the Baltimore-Washington Young Stroke Study. Neurology. 1998;50(6):1688-93.

10. Demarin V, Lisak M, Morović S. Mediterranean diet in healthy lifestyle and prevention of stroke. Acta Clin Croat. 2011;50(1):67-77.

11. Kadojić D. Epidemiologija moždanog udara (Epidemiology of stroke). Presented at Šesti kongres Hrvatskoga društva za neurovaskularne poremećaje Hrvatskoga liječničkog zbora s međunarodnim sudjelovanjem, 2012. Available at: http://bib. irb.hr/prikazi-rad?rad=606373 (retrieved November 2015) (in Croatian)

12. O’Donnell MJ, Xavier D, Liu L, et al.; Interstroke Investigators. Risk factors for ischaemic and intracerebral haemorrhagic stroke in 22 countries (the INTERSTROKE study): a case-control study. Lancet. 2010;376(9735):112-23, doi: 10.1016/S0140-6736(10)60834-3.

13. Kim AS, Johnston SC. Globalvariation in the relative burden of stroke and ischemic heart disease. Circulation. 2011;124(3):31423, doi: 10.1161/CIRCULATION AHA.111.018820.

14. Ayala C, Croft JB, Greenlund KJ, et al. Sex differences in US mortality rates for stroke and stroke subtypes by race/ethnicity and age, 1995-1998. Stroke. 2002;33(5):1197-201.

15. Kolominsky-Rabas PL, Weber M, Gefeller O, Neundoerfer B, Heuschmann PU. Epidemiology of ischemic stroke subtypes according to TOAST criteria: incidence, recurrence, and long-term survival in ischemic stroke subtypes: a population-based study. Stroke. 2001;32(12):2735-40.

16. Griffiths D, Sturm J. Epidemiology and etiology of young stroke. Stroke Res Treat. 2011, Article ID 209370, http:// dx.doi.org/10.4061/2011/209370.

17. Yamamoto FI. Ischemic stroke in young adults: an overview of etiological aspects. Arq Neuropsiquiatr. 2012;70(6):462-6.

18. Cerratoa P, Grassoa M, Imperialeb D, et al. Stroke in young patients: etiopathogenesis and risk factors in different age classes. Cerebrovasc Dis. 2004;18:154-9.

19. Ay H, Furie KL, Singhal A, Smith WS, Sorensen AG, Koroshetz WJ. An evidence-based causative classification system for acute ischemic stroke. Ann Neurol. 2005;58(5):688-97.

20. Reeves MJ, Fonarow GC, Zhao X, Smith EE, Schwamm $\mathrm{H}$; Get With The Guidelines-Stroke Steering Committee \& Investigators. Quality of care in women with ischemic stroke in the GWTG program. Stroke. 2009;40(4):1127-33, doi: 10.1161/STROKEAHA.108.543157.
21. Silva GS, Lima FO, Camargo EC, et al. Gender differences in outcomes after ischemic stroke: role of ischemic lesion volume and intracranial large-artery occlusion. Cerebrovasc Dis. 2010;30(5):470-5, doi: 10.1159/000317088.

22. Andersen KK, Andersen ZJ, Olsen TS. Predictors of early and latecase-fatalityin a nationwideDanish studyof 26,818 patients with first-ever ischemic stroke. Stroke. 2011;42(10):2806-12, doi: 10.1161/STROKEAHA.111.619049.

23. Nedeltchev K, Der Maur TA, Georgiadis D, et al. Ischaemic stroke in young adults: predictors of outcome and recurrence. J Neurol Neurosurg Psychiatry. 2005;76:191-5, doi: 10.1136/ jnnp.2004.040543.

24. Emerging Risk Factors Collaboration; Kaptoge S, di Angelantonio $\mathrm{E}$, et al. C-reactive protein concentration and risk of coronary heart disease, stroke, and mortality: an individual participant meta-analysis. Lancet. 2010;375(9709):132-40. doi: 10.1016/S0140-6736(09)61717-7.

25. Lin MP, Ovbiagele B, Markovic D, Towfighi A. "Life's simple 7" and long-term mortality after stroke. J Am Heart Assoc. 2015;4(11), pii: e001470, doi: 10.1161/JAHA.114.001470.

26. Esteghamati A, Morteza A, Khalilzadeh O, et al. Physical inactivity is correlated with levels of quantitative $\mathrm{C}$-reactive protein in serum, independent of obesity: results of the national surveillance of risk factors of non-communicable diseases in Iran. J Health Popul Nutr. 2012;30(1):66-72.

27. Lovrenčić-Huzjan A, Strineka M, Šimičević DS, et al. Management of patients with transient ischemic attack (TIA) at Sestre milosrdnice University Hospital Center. Acta Clin Croat. 2011;50(3):367-73.

28. Saleem F, Hassali M, Shafie A, Atif M. Drug attitude and adherence: a qualitative insight of patients with hypertension. J Young Pharm. 2012;4(2):101-7, doi: 10.4103/09751483.96624

29. Guidetti D, Baratti M, Zucco R, et al. Incidence of stroke in young adults in the Reggio Emilia area, Northern Italy. Neuroepidemiology. 1993;12(2):82-7.

30. Wolf PA, Abbott RD, Kannel WB. Atrial fibrillation as an independent risk factor for stroke: the Framingham Study. Stroke. 1991;22:983-8.

31. Whisnant JP. Effectiveness versus efficacy of treatment of hypertension for stroke prevention. Neurology. 1996;46(2): 301-7.

32. Niewada M, Kobayashi A, Sandercock PA, Kamiński B, Członkowska A; International Stroke Trial Collaborative Group. Influence of gender on baseline features and clinical outcomes among 17,370 patients with confirmed ischaemic stroke in the international stroke trial. Neuroepidemiology. 2005;24(3):123-8. 
Sažetak

\section{DOBNE I SPOLNE RAZLIKE U BOLESNIKA S AKUTNIM MOŽDANIM UDAROM}

\section{Bašić Kes, M.-J. Jurašić, I. Zavoreo, M. Lisak, V. Jeleč i L. Zadro Matovina}

Moždani udar je drugi uzrok smrtnosti i najvažniji uzrok invaliditeta u odraslih u svijetu i u Hrvatskoj. Nekada se moždani udar smatrao isključivo bolešću starijih; ipak, danas se dobna granica sve više snižava prema mlađoj dobi. Cilj ovoga istraživanja bio je utvrditi utjecaj dobi i spola u bolesnika s moždanim udarom u gradskom području u Hrvatskoj tijekom jedne godine. Istraživanje je uključilo sve bolesnike s akutnim moždanim udarom primljene u našu Kliniku tijekom 2004. godine. Medicinski upitnik je bio ispunjen tijekom primanja u bolnicu i uključivao je sljedeće kategorije: čimbenike rizika (pušenje i alkohol), procjenu tjelesnih sposobnosti prije nastupa moždanog udara, podatke o tijeku moždanog udara, laboratorijske nalaze i nalaze kompjutorizirane tomografije, podatke o ishodu i procjenu tjelesne onesposobljenosti kod otpusta. Obavljena je prikladna statistička analiza na numeričkim i kategorijskim podacima, a razina statističke značajnosti označena na $\mathrm{p}<0,05$. U ispitivanje je bilo uključeno 396 bolesnika, 24 od njih pripadalo je skupini mlađih bolesnika. Starija skupina bolesnika imala je veći stupanj invalidnosti kod otpusta, a žene su imale veći stupanj invalidnosti prije nastupa moždanog udara i kod otpusta, vjerojatno zbog više dobi u trenutku nastupa moždanog udara. Mlađa skupina bolesnika oporavljala se bolje i s manjim ostatnim deficitom, dok su stariji bolesnici trebali češće potražiti pomoć u sekundarnim medicinksim ustanovama, kao što se i očekivalo. Najvažniji laboratorijski nalaz tijekom hospitalizacije kod mlađih bolesnika bile su povišene vrijednosti lipida, dok su kod starijih zabilježene povišene vrijednosti serumske glukoze i C-reaktivnog proteina. U mlađih bolesnika moždani udar je češće započinjao naglom snažnom glavoboljom, a i epileptički napadaj kao prvi simptom zaabilježen je s većom učestalošću od očekivane. Analiza čimbenika rizika pokazuje da su žene sklonije arterijskoj hipertenziji, kroničnom zatajenju srca i atrijskoj fibrilaciji, a muškarci su češće pušači i imaju sklonost povećanom unosu alkohola. Nadalje, analiza prema dobi je pokazala da su srčane bolesti i pušenje češći kod starijih bolesnika s moždanim udarom. Zaključno, mnogobrojne razlike su utvrđene među skupinama bolesnika podijeljenim po dobi i spolu, potvrđujući potrebu za uspostavom trajnog nacionalnog registra za praćenje bolesnika s moždanim udarom kako bi se mogli poduzeti ciljani koraci u sekundarnoj njezi i prevenciji bolesnika s moždanim udarom, najbolje osobno prilagođenim, a s posebnim osvrtom na čimbenike rizika za cerebrovaskularne bolesti.

Ključne riječi: Moždani udar; Rizični čmbenici; Hrvatska; Spol; Dob; Ankete i upitnici 